\title{
Recent Comparative Studies on the Performance and Survival Rate of African Catfish (Clarias gariepinus) Larval Produced under Natural and Synthetics Hormones: A Review
}

\author{
Sebastian S Mosha* \\ Training Department, Ministry of Agriculture Training Institute (MATI), P.O. Box 121, Mtwara, Tanzania
}

\begin{abstract}
Induced breeding in African catfish (C. gariepinus) became germane in addressing unreliable seed supply due to low fertilization and egg hatchability, improper selection and use of natural or synthetic hormones to induce ovulation and spawning. The proper use of hormones promote reproduction in fish which is controlled by several factors such as sex steroids in the regulation of reproductive processes which are controlled through the brain-pituitary gonadal axis. A review was conducted on recent comparative studies on the performance and survival rate of African catfish (C. gariepinus) larval produced under natural and synthetics hormones. More than 20 journal published papers on inducing ovulation and spawning in African catfish (C. gariepinus) either by using natural or synthetic hormones, mostly from West Africa were reviewed. Literatures suggested that, using synthetic or non- synthetic hormones ensure availability of matured quality eggs, and ensuring good and viable milt production for commercial fish farming. Among reviewed papers revealed that, higher fertilization, hatching and survival rate of African catfish larval were achieved at $0.4-0.5 \mathrm{ml} / \mathrm{kg}$ of Ovaprim compared to Ovatide, Ovulin and Pituitary Gland Extract. In ovarian lavage with combination of sperm and hormone method, the simplicity of induced spawning can be combined, with a less time dependent delivery of sperm than with conventio na I, in-vitro fertilization. Therefore, this review suggests that African catfish seeds production can be encouraged through the use of Ovaprim. However, Catfish Pituitary Gland Extract (CPE) which is more readily available at farm level can also be used in-vitro fertilization in case there will be any shortage of Ovaprim whose supply varies with changes in import duties. In addition, to optimize fertilization and larval rearing pituitary gland extract in combination with disinfectants such as FA and MG can be used.
\end{abstract}

Keywords: Synthetic hormones; Pituitary gland extract; Induced breeding; African catfish; Larval performance and survival rate

\section{Introduction}

The African catfish, Clarias gariepinus Burchell 1822, is the favorite fish for aquaculture in West Africa [1] and other parties of the African continent. The species is dominant in freshwater environments including lakes, rivers and dams. C. gariepinus has been preferably in aquaculture due to its ease of culturing, fast growth rate, high resistance to disease, tolerance of a wide range of temperature, low dissolved oxygen as well as high salinity levels and most importantly high commercial value $[2,3]$. In East Africa, its demand has increased as food, control of overpopulation in tilapia ponds and as a bait for the Nile perch fishery [4]. In Tanzania, it has gained popularity in the aquaculture sector in the recent past times [5].

This species is not readily breed in captivity [6] all year round, therefore most farmers depend on fingerlings collected from the wild.

However, due to problems associated with wild fish seed such as seasonality in availability, uncertainty of species of fish seed collected, disease infestation and limited quality of harvestable fish seed $[7,8]$, wild sources are unreliable and hence the need for seeds production using hormones. The hormones promote reproduction in fish which is controlled by several factors such as sex steroids in the regulation of reproductive processes [9]. These reproductive processes are controlled through the brain-pituitary gonadal axis. The brain is stimulated by environmental cues (water rise, temperature, feeding, rainfall, and photoperiod) to release gonadotropin releasing hormones [10]. Then, ovulation and spermiation are affected as a result of the sex steroids that have been produced [11]. Administration of these hormones to induce ovulation and spawning in fish is achieved through artificial propagation with either natural or synthetic hormones $[12,13]$.
Artificial propagation of African catfish (C. gariepinus) is the most promising and reliable way of ensuring large scale production of quality fish seeds throughout the year and sustainability of the aquaculture sector [14]. Induced breeding in African catfish became germane in addressing unreliable seed supply due to low fertilization and egg hatchability, and improper selection and use of hormones to induce ovulation and spawning. Therefore, this study reviewed on recent comparative studies on the performance and survival rate of African catfish (C. gariepinus) larval produced under natural and synthetics hormones.

\section{Literature Review}

\section{Natural hormones}

A large number of natural spawning agents for induced breeding of the African catfish C. gariepinus are available and these include Deoxycorticosterone Acetate (DOCA), Human Chorionic Gonadotropin (HCG) and Pituitary Gland Extract (PGE) [15]. These hormones are known to be used successfully, however they are deficient in various ways, such as Deoxycorticosteroid Acetate (DOCA) causes severe ulcer on the

${ }^{*}$ Corresponding author: Sebastian S Mosha,Training Department, Ministry of Agriculture Training Institute (MATI), P.O. Box 121, Mtwara, Tanzania, Tel: +918300983373; E-mail: seblym2012@yahoo.com

Received March 21, 2018; Accepted April 08, 2018; Published April 16, 2018

Citation: Mosha SS (2018) Recent Comparative Studies on the Performance and Survival Rate of African Catfish (Clarias gariepinus) Larval Produced under Natural and Synthetics Hormones: A Review. J Aquac Res Development 9: 528. doi: 10.4172/2155-9546.1000528

Copyright: (c) 2018 Mosha SS. This is an open-access article distributed unde the terms of the Creative Commons Attribution License, which permits unrestricted use, distribution, and reproduction in any medium, provided the original author and source are credited. 
Citation: Mosha SS (2018) Recent Comparative Studies on the Performance and Survival Rate of African Catfish (Clarias gariepinus) Larval Produced under Natural and Synthetics Hormones: A Review. J Aquac Res Development 9: 528. doi: 10.4172/2155-9546.1000528

Page 2 of 6

injected female, Human Chronic Gonadotropin (HCG) is expensive [16], and Pituitary Gland Extract (PGE) is difficult to quantify $[17,18]$.

\section{Pituitary Gland Extract (PGE)}

Pituitary gland is the main source of the major hormones responsible for reproduction in catfish and other farmed species. The hormonal induction involves the injection of pituitary gland extract from the donor fish of equivalent weight $[19,20]$ or from other species to the female spawned. Pituitary gland secretes the gonadotropins such as Follicle Stimulating Hormone (FSH) and Luteinising Hormone (LH). FSH causes growth and maturation of ovarian follicles in females and spermatogenesis in the testes of males. LH cause Luteinisation in females and promote the production of testosterone in males [21]. The pituitary cells have been reported to undergo continuous mitotic process [22]. It can be cultured and proliferated in-vitro in order to use their secretions for induction of spawning in catfish. The extracted gland which contain hormones are grinded in a motor and pestle and mixed with normal saline solution $(0.9 \% \mathrm{NaCl}) .1 \mathrm{ml}$ is administered to the female brood stocks in between the dorsal fin and the lateral line towards the abdominal region using syringe and needle [23].

The pituitary gland extract has advantages of better rate of fertilization and hatching, better conditions for growth and survival of larvae [24]. In addition, it enhances free release of eggs from the genital papilla of female broodstock, and stimulation the release of hormones into the blood circulatory system which induced ovulation and production of mature eggs [3]. Also, African catfish pituitary hormone is said to be readily available and cheaper than any other hormone [25] and can be prepared in a suspension [19]. However, the extraction of the pituitary gland from other donor species is a challenge. For instance, Commoncarp (Cyprinus carpio) pituitary gland materials are not easily accessible [16].

\section{Synthetics hormones}

The use of synthetic hormones in African catfish particularly a female fish is now popular as a means of artificially inducing the female fish in order to ovulate. These includes synthetic gonadotrophin releasing hormone analogues (GNRH-a) which are administered to the female brood stocks [23]. Gonadotropin Releasing Hormone analogue (GnRHa) is now the best available biotechnological tool for the induced breeding of fish. These includes the following which have been used to induce breeding successfully, Ovaprim, Ovatide, Ovaryprim, Ovopel, Ovupin-L, Ovulin, Dagin and Aquaspawn [12,13,26-28]. Among Gonadotropin Releasing Hormone analogue (GnRHa), Ovaprim and Ovatide containing salmon gonadotropin releasing hormone analogue and domperidone (SGnRHa + Domperidone) which are usually used for spawning induction in catfishes to get quality seed [29]. In addition, for large scale production in hatcheries, the use of hormones may be the solution for massive production. However, some of these hormones particularly Ovaprim is usually expensive $[17,18,30]$.

\section{Ovaprim}

Ovaprim consists of GnRH-a and dopamine receptor antagonist, domperidone. It is developed by Dr. Lin of China and Dr. Peter of Canada [31]. It is marketed in liquid form and does not require any special preparation [32]. Ovaprim reported to significa ntly increase ovulation in African catfish [33] and aid spawning in the matured female Catfish. According to Watson et al. [32], the average success rates of $50 \%$ ovulation, $54 \%$ spermiation and $1.3 \%$ mortality were recorded after injection of different species with Ovaprim. Also, it has been used successfully for hypophysation in different families of fish like cyprinidae [34], Characidae and Cobitiidae [22].

\section{Ovatide}

Synthetic compound contains GnRH analogue with dopamine antagonist, pimozide and marketed in a pelleted form Indian major carp [31]. During administering, pellet should be powdered and mixed with saline solution $(0.65 \% \mathrm{Nacl}) 12$ hour before injecting the female fish to stimulate ovulation and spawning.

\section{Other substances used for induced breeding}

Other substances like LH-RH analogues, steroids, HCG and clomiphene can used for inducing breeding [31]. During breeding induction, environmental factors such as temperature, DO and light are very important factors for the success since they control the reproduction of fish.

\section{Comparative Studies}

Among research papers reviewed, Ovaprim, Pituitary Gland Extract (PGE), Ovatide and Ovulin are the hormones which were mostly used.

\section{Ovaprim $(0.4 \mathrm{ml} / \mathrm{kg})$ and Pituitary Gland Extract $(1 \mathrm{ml} / \mathrm{kg})$}

Induced breeding of African catfish (C. gariepinus) by using Ovaprim or Pituitary Gland Extract (PGE) ensures availability of fish seeds in hatcheries for commercial fish farming. These two hormones can be used separately or in a combination. Krol et al. [35] reported that, using a combination of these two hormones bring about quick ovulation and higher percentage of hatched fish, though Ovaprim hormone gives higher yield than the natural hormones (PGE). In addition, Oyeleye et al. [3], reported higher fertilization rates and eggs spawned when Ovaprim $(0.4$ $\mathrm{ml} / \mathrm{kg}$ ) used compared to Fresh Pituitary Gland $(1 \mathrm{ml})$ administered to matured catfish female after 10 hours of inducement at $27^{\circ} \mathrm{C}$. While, there was no significant difference in hatchability rates among eggs ovulated using Ovaprim (Table 1). The similar results reported by Fagbenro, Nagahama and Yamashita [19,36,37].

\section{Ovaprim $(0.5 \mathrm{ml} / \mathrm{kg})$ and pituitary gland extract $(1 \mathrm{ml} / \mathrm{kg})$}

High concentration of synthetic hormones reported to increase the egg hatchability and survival rate of larval over natural hormones. Olaniyi and Akinbola [16], reported that, the values obtained for the spawning response when female (average weight of $1160 \mathrm{~g}$ ) induced with $0.5 \mathrm{ml} /$ $\mathrm{kg}$ of ovaprim and $1 \mathrm{ml} / \mathrm{kg}$ of African Catfish Pituitary Gland (ACPG) hormone treatments and kept for 9.05 hours after injection at a constant temperature of $27^{\circ} \mathrm{C}$ were significantly $(\mathrm{p}<0.05)$ higher in ovaprim than in ACPE (Table 2). The similar results reported by Saidin [38].

However, Shourbela et al. [2] reported the lower hatching rates ranged between $51.1 \%$ to $73 \%$ in the different hormone treatments. Also, Nagahama and Yamashita [36] observed that, yolk absorption was faster in fries produced from ACPE and was completed after 3days while fries produced from ovaprim took about 5 days to be completed. In addition, faster growth rate and survival rate of fries after 4 weeks were also observed in ACPE compared to ovaprim. Similarly, Adebayo and Popoola [25] observed survival rate of greater than $60 \%$ after 30 days of rearing.

\section{Ovaprim $(0.5 \mathrm{ml} / \mathrm{kg})$ and Ovatide $(0.3 \mathrm{ml} / \mathrm{kg})$}

Most of the literatures suggest that, Ovaprim produces best results in inducing ovulation and spawning in African catfish than Ovatide. This might be due to a higher level of the hypothala mus pituitary gonad axis than gonadotropins resulted from GnRHa. Consequently, GnRH can provide a more balanced stimulation of reproductive events and presumably a better integration of these events with other physiological 
Citation: Mosha SS (2018) Recent Comparative Studies on the Performance and Survival Rate of African Catfish (Clarias gariepinus) Larval Produced under Natural and Synthetics Hormones: A Review. J Aquac Res Development 9: 528. doi: 10.4172/2155-9546.1000528

Page 3 of 6

\begin{tabular}{|c|c|c|c|}
\hline Inducer & Weight of egg spawned (g/kg) & Fertilization (\%) & Hatchability (\%) \\
\hline N & 4 & 4 & 4 \\
\hline FPG & $127.5 \pm 11.54^{\mathrm{b}}$ & $81.54 \pm 2.42^{\mathrm{b}}$ & $75.43 \pm 3.34^{\mathrm{a}}$ \\
\hline Ovaprim & $157 \pm 13.66^{\mathrm{a}}$ & $87.34 \pm 1.32^{\mathrm{a}}$ & $76.54 \pm 1.21^{\mathrm{a}}$ \\
\hline
\end{tabular}

Means in the same column with the same letter are not significantly different $p>0.05$.

FPG: Fresh Pituitary Gland; Ovaprim: GnRH analogue. N: Sample Size [3].

Table 1: Induced spawning with fresh and cultured cell solutions.

\begin{tabular}{|c|c|c|c|}
\hline \multirow[t]{2}{*}{ Parameters } & \multicolumn{3}{|c|}{ Hormones } \\
\hline & Ovaprim & ACPE & SEM \\
\hline $\mathrm{ABW}(\mathrm{g})$ & $\mathrm{ABW}(\mathrm{g})$ & 1160.00 & 0.01 \\
\hline $\operatorname{MEW}(g)$ & $116.75^{\mathrm{b}}$ & $177.98^{a}$ & 0.11 \\
\hline TNE (g) & $35901.50^{\mathrm{b}}$ & $90861.00^{\mathrm{a}}$ & 32.46 \\
\hline Relative fecundity & $30.95^{\mathrm{b}}$ & $78.33^{a}$ & 0.19 \\
\hline Hatchability (\%) & $46.30^{\mathrm{a}}$ & $25.99^{b}$ & 1.01 \\
\hline Survival (\%) & $50.14^{b}$ & $82.89^{a}$ & 0.04 \\
\hline Hatching periods (hrs) & 48.00 & 48.00 & 0.00 \\
\hline Latency (hrs) & 9.05 & 9.05 & 0.03 \\
\hline
\end{tabular}

Means in the same row with different superscripts $(a, b)$ are significantly different $(p<0.05)$

ABW: Average Body Weight, MEW: Mean Egg Weight, SEM: Standard Error of Mean TNE; Total

Number of Eggs, ACPE: African Catfish Pituitary Extract. Source: [16].

Table 2: Induced ovulation and spawning of Clarias gariepinus using synthetic (ovaprim) and non-synthetic (ACPE) hormones.

functions, by directly or indirectly affecting the release of other hormones necessary for successful spermiation [39]. In case of males Gbemisola and Adebayo [37] reported that, milt from males administered with ovaprim $(0.5 \mathrm{ml} / \mathrm{kg})$ had higher percentage fertilization, hatchability, and survival than ovatide $(0.3 \mathrm{ml} / \mathrm{kg})$ induced hormone (Table 3$)$. The similar results have been reported by other researches such as Mylonas et al., Clearwater, Crim, Ndimele, Owodeinde and Adebiyi et al. [40-43].

\section{Combined hormones (Ovaprim +Ovulin)}

Among papers reviewed on a synthetic hormones combination, Ovaprim and Ovulin seemed to be featured as the best when treated with others. According to Kutwal et al. [15], the effect of hormone manipulation on fecundity indicated that combined hormonal treatment $3(75 \%$ Ovaprim $+25 \%$ Ovulin) had significantly $(\mathrm{p}<0.05)$ higher weight of eggs produced, fertilization, hatchability, and survival rate than other treatments (Table 4). The similar results are reported by Audu and Yisa et al. [44,45].

\section{Ovarian lavage with combination of sperm and hormone (Sperm + Pituitary gland extract)}

Ovarian lavage is a technology in breeding induction for finfish where African catfish (Clarias gariepinus) are used as a model fish [14] in most of experiments. It involves the injection of a sperm and pituitary gland extract mixture into the ovary through the oviduct. Both catfish and carp pituitary extract glands with a specific fish's sperm have been reported to be used successfully. Müller et al. [46] reported that, sperm injection into the ovary through the oviduct leads to successful recovery of developing embryos after delivering sperm to eggs in carp. This result indicates that spermatozoa are stored in the ovary and oviduct for up to 12 hours without loss of biological activity and that ovulated eggs could be fertilized after being released from the body cavity. In recent study, Müller et al. [46] reported significantly $(\mathrm{p}<0.05)$ higher fertilization percentages in both G1 and G2 groups of African catfish (1366 $\pm 164.1 \mathrm{~g}$ bodyweight) when sperm samples were treated with $3 \mathrm{mg} \mathrm{CPE} / 1 \mathrm{ml}$ and $0.9 \%$.

$\mathrm{NaCl}$ solution/kg bodyweight injected intraperitoneally, 20 hours prior to the egg stripping of females (Table 5). Similarly, Watson et al. [32] published that Tetraodon nigroviridis was used to develop an alternative method for application of hCG via direct lavage into the ovaries. In addition, Németh et al. [47] presented that a non-invasive method of ovarian lavage is, as equally suitable method for the induction of ovulation in pikeperch (Sander lucioperca), as the traditionally used intramuscular injection of hormonal products using CPE.

\section{Combining hormones and disinfectants (Pituitary gland + Formalin and Malachite green)}

The optimization of fertilization and larval survival rate can be achieved through controlling of infections at the early stage of development. In farming catfish, Saprolegnia fungal infection have been reported to cause egg mortality and reduces hatchability of viable fertilized fish eggs, leading to a huge loss to aquaculture industry [2]. Therefore, several chemotherapeutics have been examined and used as curative agents for external ciliated protozoan parasites in food fishes $[48,49]$. Among these, Formalin (FA), malachite green (MG) and sodium chloride are very good examples of the therapeutants applied in aquaculture. Shourbela et al. [2] reported that, the ovulation percentage for the FA-treated groups was greater than the MG-treated broodfish when CPE used at the same latency periods. Similar results reported by Hossain et al., Sahoo et al., and El-Hawarry et al., [50-52]. In contrary, Adeyemo et al. $[53,54]$ found that, the fertilized eggs of the FA and MG treated groups did not hatch and did not develop as normally as those eggs collected from the non-treated broodfish.

\section{Discussion}

Basing on the reviewed research papers, Ovaprim $(0.4-0.5 \mathrm{ml} / \mathrm{kg})$ has been known to have better results because of its potency and quality as well as its relatively cheaper cost, ease handling and better survival of hatchlings [12]. However, Orji et al., [55] stated its limitations on induced spawning thus farmers encounter shortage of fingerlings with which to stock their ponds irrespective of many hatcheries in different locations. Failure in fertilization and hatching during induced spawning may also be due to environmental and physico-chemical factor such as salinity. In addition, the price of Ovaprim increases indiscriminately due to import duties. Therefore, to reduce the cost of production arising from purpose of Ovaprim, there is need to find an alternative 
Citation: Mosha SS (2018) Recent Comparative Studies on the Performance and Survival Rate of African Catfish (Clarias gariepinus) Larval Produced under Natural and Synthetics Hormones: A Review. J Aquac Res Development 9: 528. doi: 10.4172/2155-9546.1000528

Page 4 of 6

\begin{tabular}{|c|c|c|}
\hline Parameters & Ovatide & Ovaprim \\
\hline Fertilization (\%) & $87.73 \pm 3.38^{\mathrm{b}}$ & $94.40 \pm 2.03^{\mathrm{b}}$ \\
\hline Hatchability (\%) & $59.7 \pm 0.88^{\mathrm{b}}$ & $66.37 \pm 0.74^{\mathrm{c}}$ \\
\hline Survival (\%) & $63.56 \pm 13.56^{\mathrm{a}}$ & $77.38 \pm 5.95^{\mathrm{a}}$ \\
\hline Hatching time & $23.5 \pm 0.50^{\mathrm{a}}$ & $24 \quad 00^{\mathrm{a}}$ \\
\hline Hatching period & $72 \pm 00$ & $72 \pm 00$ \\
\hline Mean values in the same row having the same superscript are not significantly different. Source: [37] & \\
\hline
\end{tabular}

Table 3: Reproductive performance of induced male sperm on fertility, hatchability and survival percentage of $C$. gariepinus egg

\begin{tabular}{|c|c|c|c|}
\hline TRT & Wt of eggs $\mathbf{( g )}$ & \% Fertilization & \% Hatchability \\
\hline TRT1 & 161 & 72.50 & 76.22 \\
\hline TRT2 & 159 & 75.40 & 81.25 \\
\hline TRT3 & 175 & 87.41 & 93.90 \\
\hline TRT4 & 169 & 75.20 & 84.75 \\
\hline TRT5 & 165 & 76.70 & 83.35 \\
\hline Mean & $166 \pm 2$ & $75083 \pm 7645.4$ & 38.90 \\
\hline
\end{tabular}

Where TRT-Treatment; TRT1-(100\% Ovaprim); TRT2-(100\% Ovulin); TRT3-(75\% Ovaprim + 25\% Ovulin); TRT4-(50\% Ovaprim + 50\% Ovulin) and TRT5-(25\% Ovaprim $+75 \%$ Ovulin) Source: [15].

Table 4: Mean induced ovulation and spawning of Clarias gariepinus using two synthetic hormones (Ovaprim and Ovulin) and effect of the hormones on weight of eggs, fertilization, hatchlings and survival rate.

\begin{tabular}{|c|c|c|c|c|c|c|}
\hline \multirow[t]{2}{*}{ Exp. } & \multirow[b]{2}{*}{ Samp.no } & \multirow[b]{2}{*}{ Treatment } & \multirow[b]{2}{*}{$B W(g)$} & \multirow[b]{2}{*}{ PGSI(\%) } & \multicolumn{2}{|c|}{ Fertilization rate $(\%)$} \\
\hline & & & & & $\begin{array}{l}\text { No additional } \\
\text { sperm }\end{array}$ & $\begin{array}{l}\text { With additional } \\
\text { fresh sperm }\end{array}$ \\
\hline G1 & 1 & \multirow{5}{*}{ CPE + sperm } & \multirow{3}{*}{1244} & \multirow{3}{*}{11.1} & \multirow{3}{*}{$73.4 \pm 0.6$} & \multirow{3}{*}{-} \\
\hline \multirow{7}{*}{ G2 } & & & & & & \\
\hline & 2 & & & & & \\
\hline & & & 890 & 10.8 & $66.9 \pm 5.1$ & - \\
\hline & 3 & & 1134 & 8.6 & $68.7 \pm 6.9$ & - \\
\hline & 4 & $\begin{array}{l}\mathrm{NaCl} \text { dissolved } \mathrm{CPE} \text { to } \\
\text { right ovary }\end{array}$ & 1078 & 10.2 & $94.9 \pm 0.8$ & - \\
\hline & 5 & Sperm without CPE to left ovary & 780 & 10.0 & $80.5 \pm 4.1$ & - \\
\hline & 6 & CPE + sperm & 1322 & 7.3 & $91.1 \pm 2.6$ & $90.3 \pm 4.1$ \\
\hline & 7 & & 518 & 13.0 & $76.7 \pm 3.9$ & $72.7 \pm 6.3$ \\
\hline & 8 & & 640 & 9.2 & $93.7 \pm 0.8$ & $87.8 \pm 2.2$ \\
\hline & 9 & & 1000 & 11.3 & $78.7 \pm 2.0$ & $60.6 \pm 4.5$ \\
\hline & 10 & & 464 & 10.1 & $83.7 \pm 2.3$ & $71.7 \pm 2.7$ \\
\hline & 11 & & 778 & 9.0 & $57.8 \pm 9.7$ & $76.7 \pm 10$ \\
\hline & 12 & & 1598 & 6.1 & $41 \pm 4.4$ & $65.7 \pm 8.8$ \\
\hline $\begin{array}{l}\text { Sum. } \\
\text { G2 }\end{array}$ & & & $902.9 \pm 427$ & $9.4 \pm 2.3$ & $74.7 \pm 18.4$ & $75.1 \pm 11.5$ \\
\hline
\end{tabular}

Table 5: Summarized data which represent means and standard deviations (Means \pm SD).

cheaper spawning aid [16]. Several techniques have been developed, such as multiple ovaprim dilution technique. This technique involves using diluted Ovaprim. Several studies have been conducted and promised results to have been reported with the same time achieving a high spawning, hatchability and survival success of the fish. Olumuji and Mustapha [8] reported that normal saline diluted Ovaprim at $75 \%$ and $50 \%$ is effective in induced breeding of Clarias gariepinus. Also, he found that, production and hatchability of eggs as well as survival of fry which compared well with undiluted Ovaprim. Therefore, the normal saline could enhance the production, hatchability of eggs and survival of fry. The similar results reported by Shepherd and Bromage [7,17]. However, Olumuji and Mustapha [8] found the percentage survival was relatively lower compared to results obtained by Nwokoye et al. study [12]. This could be attributable to the size of the receptacle (tank) in which the experiment was conducted which was relatively smaller and also more eggs were fertilized, and the tank was not power-aerated as reported by Olumuji and Mustapha [8]. On the other hand, natural hormone (ACPE) which is more readily available can also be used in case there will be shortage of Ovaprim whose supply varies with changes in import duties.

In-vitro fertilization of fish, some advances has been reported by several scientists. Müller et al. [46] suggested that, it may be possible to propagate without the presence of males in spontaneous spawning fish species, which release ovulated eggs spontaneously [24,56-61]. 
Citation: Mosha SS (2018) Recent Comparative Studies on the Performance and Survival Rate of African Catfish (Clarias gariepinus) Larval Produced under Natural and Synthetics Hormones: A Review. J Aquac Res Development 9: 528. doi: 10.4172/2155-9546.1000528

Therefore, the method can be applicable in the field of aquaculture management where it is important to increase genetic diversity. For instance, in induced spawning of paired spawning fish species (such as Sander lucioperca, Silurus glanis, Umbra krameri etc.) 5-10 sperm samples can be used from different males, for fertilization [46]. In addition, during fertilization care should be taken to prevent infection in the eggs. Several chemotherapeutics such as Formalin (FA), malachite green (MG) and sodium chloride [49] have been examined [48,49-61].

\section{Conclusion}

Generally, induce breeding in African catfish (C. gariepinus) by using synthetic or non- synthetic hormones ensure availability of matured quality eggs and high survival rate of larval for commercial fish farming. For males, it helps in boosting reproductive performance and ensuring good and viable milt production. In-vitro fertilization, ovarian lavage with combination of sperm and hormone method can be used since simplify the induction of spawning with a less time dependent delivery of sperm. In addition, the review revealed that higher fertilization, hatching and survival rate were achieved when Ovaprim used at $0.4-0.5 \mathrm{ml} / \mathrm{kg}$ of fish compared to Ovatide and Pituitary Gland Extract (PGE). Therefore, the review suggests that African catfish seeds production can be encouraged through the use of synthetic hormone particularly Ovaprim for better results in ovulation and pawning of eggs. Also, to optimize fertilization and larval rearing pituitary extracted gland in combination of disinfectants such as FA and MG can be used.

\section{Acknowledgment}

I acknowledge all journals and researchers who I have used their valuable research findings for the preparation of this review. This paper is a contribution of knowledge in farming of African catfish (C. gariepinus).

\section{References}

1. Adewumi AA, Olaleye VF (2011) Catfish culture in Nigeria: Progress, prospects and problems. Afr J Agric Res 6: 1281-1285.

2. Shourbela RM, Tohamy HG, El-Hawarry WN (2019) Induced spawning of African catfish (Clarias gariepinus Burchell 1822) after pre-spawning prophylactic disinfection: The breeding performance and tissue histopathological alterations are under scope. Iranian Journal of Fisheries Sciences 18: 2.

3. Oyeleye OO, Ola SI, Omitogun OG (2016) Ovulation induced in African catfish (Clarias gariepinus, Burchell 1822) by hormones produced in the primary culture of pituitary cells. International Journal of Fisheries and Aquaculture. 8: 67-73.

4. Musiba MJ, Ngupula GW, Kashindye BB, Elison M, Shoko AP, et al. (2014) Performance of locally formulated feeds for rearing of African catfish in Tanzania. African Crop Science Journal 22: 979-986

5. Mosha SS, Kang OJ, Jere W, Madalla N (2016) Effect of organic and inorganic fertilizers on natural food composition and performance of African catfish (Clarias gariepinus) fry produced under artificial propagation. J Aquac Res Development 7: 441

6. Adebayo OT, Fagbenro OA (2004) Induced ovulation and spawning of pond raised African giant catfish Heterobranchus bidorsalis by exogenous hormones. Aquaculture 242: 229-236.

7. Shepherd CJ, Bromage NR (1988) Intensive fish farming. Blackwell science Ltd., 404.

8. Olumuji OK, Mustapha MK (2012) Induced breeding of African Mud catfsh, Clarias gariepinus (Burchell 1822), using different doses of normal saline diluted ovaprim. J Aquacult Res Dev 3: 133

9. Kime DE (1993) Classical and non-classical reproductive steroids in fish. Rev. Fish Biol. Fish. 3: 160-180.

10. Zhuo Q, Zhang Y, Huang W, Liu X, Li Y, et al. (2011) Gonadotropin releasing hormone analogue multiple injection potentially accelerated testicular maturation of male yellow catfish (Pelteobagrus fluridruco Richardson) in captivity. Aquacul. Res. 42: 1-14
11. Żarski D, Horváth A, Held JA, Kucharczyk D (2015) Artificial reproduction of Percid fishes. In: Kestemont P, Dabrowski K, Summerfelt R (eds.), Biology and culture of percid fishes. Springer Dordrecht pp. 123-161.

12. Nwokoye CO, Nwuba LA, Eyo JE (2007) Induced propagation of African clariid catfish. Heterobranchus bidorsalis using synthetic and homoplastic hormones. Afr. J. Biotechno 6 : 2687-2693

13. Ngueku BB (2015) The efficacy of synthetic and non-synthetic hormones in the induced spawning of the African Catfish (Clarias gariepinus Burchell, 1822). Int. J. Fish. Aquat. Studies 3: 34-37.

14. Van Oordt PGWJ, Goos HJT (1987) The African catfish, Clarias gariepinus, a model for the study of reproductive endocrinology in Teleosts. Aquaculture 63: 15-26.

15. Kutwal BY, Wokton WJ, Vou AK, Sambo AB, Okunsebor SA et al. (2017) Manipulation of synthetic hormones in induced breeding of catfish Clarias gariepinus (Burchell, 1822). International Journal of Multidisciplinary Research and Development. 4: 01-05.

16. Olaniyi CO, Akinbola DO (2013) Comparative studies on the hatchability, performance and survival rate of African catfish (Clarias gariepinus) larval produced using ovaprim and catfish pituitary extract hormones. Journal of Biology, Agriculture and Healthcare. 3: 57-62.

17. Olubiyi OA, Ayinia OA, Ayinia OA, Adeyemo AA (2005) The effects of various doses of ovaprim on reproductive performance of the African catfish Clarias gariepinus (Burchell) and Heterobranchus longiflis (Valenciennes). African Journal of Applied Zoology and Environmental Biology 7: 101-105.

18. Khan AM, Abdullah H, Ashraf SM, Ahmad Z (2006) Induced Spawning of Labeo rohita using synthetic hormones. Punjab University Journal of Zoology 21: 67-72.

19. Fagbenro OA, Salami AA, Sydenham DHL (1998) Induced ovulation and spawning in the catfish, Clarias isheriensis, using pituitary extracts from nonpiscine sources. J. Appl. Aquact. 1: 15-20

20. Salami AA, Fagbenro OA, Balogun AM, Atoyebi O, Olowoyeye MF (2006) Effective dose of amphibian pituitary extracts for the induced spawning of the Clariid Catfish, Clarias gariepinus (Burchell 1822). J Aquac. Tropics 11: 9-12.

21. Shourbela RM, Tohamy HG, El-Hawarry WN (2019) Induced spawning of African catfish (Clarias gariepinus Burchell 1822) after pre-spawning prophylactic disinfection: The breeding performance and tissue histo-pathological alterations are under scope. Iranian Journal of Fisheries Sciences 18: 2.

22. Yanong RPE, Carlos M, Craig AW (2009) Use of ovaprim in ornamental fish aquaculture. Program in fisheries and Aquatic Sciences, Institute of Food and Agricultural Sciences. University of Florida, FA161, USA

23. Oyelese OA (2006) Water temperature a determinant of fertilization and hatchability rates in artificially induced breeding of Clarias gariepinus (Teleostei: Clariidae). Res. J of Biol Sci 1: 83-87.

24. Woynárovich E, Horváth L (1980) The artificial propagation of warm-water finfishes - A manual for extension. FAO Fish. Tech. Pap. 201: 183

25. Adebayo OT, Popoola OM (2008) Comparative evaluation and efficacy and cost of synthetic and non-synthetic hormones for artificial breeding of African catfish (Clarias gariepinus). Journal of Fish Aquatic Science 3: 66-71

26. Brzuska E, Adamek J (1999) Artificial spawning of european catfish, Silurus glanis L. stimulation of ovulation using LHRH-a, ovaprim and carp pituitary extract. Aquaculture Resouces 30: 59-64.

27. Cheah MSH, Lee CL (2000) Induced ovulation of the australian eel-tailed catfish Neosilurus ater perugia with ovaprim. Asian Fish Sci 13: 87-96.

28. Zhuo Q, Zhang Y, Huang W, Liu X, Li Y, et al. (2011) Gonadotropin releasing hormone analogue multiple injection potentially accelerated testicular maturation of male yellow catfish (Pelteobagrus fluridruco Richardson) in captivity. Aquacul. Res. 42: 1-14.

29. Sahoo SK, Giri SS, Sahu AK (2005) Induced spawning of Asian catfish, Clarias batrachus (Linn): Effects of various latency periods and SGnRHa and domperidone doses on spawning performance and egg quality. Aquacult Res 36: 1273.

30. Madu CT (2006) The effects of brood stock size on the economy of catfish (Clarias anguillaris) fry production using the hormone induced natural breeding technique. J Aquat Sci 21: 19-22.

31. Surnar SR, Kamble AD, Walse NS, Sharma OP, Saini VP (2015) Hormone administration with induced spawning of Indian major carp. International Journal of Fisheries and Aquatic Studies. 3. 01-04. 
Citation: Mosha SS (2018) Recent Comparative Studies on the Performance and Survival Rate of African Catfish (Clarias gariepinus) Larval Produced under Natural and Synthetics Hormones: A Review. J Aquac Res Development 9: 528. doi: 10.4172/2155-9546.1000528

32. Watson C, Hill JE, Graves JS, Amy L, Wood A, et al. (2009) Use of a novel induced spawning technique for the first reported captive spawning of Tetraodon nigroviridis. Mar Genomics 2: 143-146.

33. Sharaf SM (2012) Effect of GnRHa, Pimozide and Ovaprim on ovulation and plasma sex steroid hormones in African catfish Clarias gariepinus. Theriogenology 77: 1709-1716.

34. Hill JE, Baldwin JD, Graves JS, Leonard R, Powell JFF, et al. (2005) Preliminary observations of topical gill application of reproductive hormones for induced spawning of a tropical ornamental fish. North American Journal of Aquaculture. 67: 7-9.

35. Krol J, Glogowski J, Demska-Zakes K, Hliwa P (2006) Quality of semen and histological analysis of testis in Perca fluviatilis L. during spawning period. Czech J. Anim. Sci. 51: 220-226.

36. Nagahama Y, Yamashita M (2008) Regulation of oocyte maturation in fish. Dev Growth Diff. 50: S195-S219.

37. Gbemisola OB, Adebayo OT (2014) Sperm quality and reproductive performance of male Clarias gariepinus induced with synthetic hormones (Ovatide and Ovaprim). Int J Fish Aquact 6: 9-15.

38. Saidin T (1986) Induced spawning of Clarias macrocephalus (Gunther); the first Asian Fisheries Forum, Macleen, J.L., Diz, L.B and Hosillos, L.V. (Eds). Asian Fisheries Society, Manila, Philippines. pp: 683-686.

39. Zohar Y, Mylonas CC (2001) Endocrine manipulation of spawning in cultured fish from hormones to genes. Aquaculture 197: 99-136.

40. Mylonas CC, Gissis A, Magnus Y, Zohar Y (1997) Hormonal changing male white bass (Morone chrysops) and evaluation of milt quality after treatmen with a sustained-release GnRHa-delivery system. Aquaculture 153: 301-313.

41. Clearwater SJ, Crim LW (1998) Gonadotropin releasing hormoneanalogue treatment increases sperm motility, seminal plasma $\mathrm{pH}$ and sperm production in yellow tail flounder Pleuronectes ferrugineus. Fish Physiol Biochem 19: 349-357.

42. Ndimele PE, Owodeinde FG (2012) Comparative reproductive and growth performance of Clarias gariepinus and its hybrid induced with synthetic hormone and pituitary gland of Clarias gariepinus. Turk J Fish Aquat Sci 12: 619-626.

43. Adebiyi FA, Siraj SS, Harmin SA, Christianus A (2013) Induced spawning of a river catfish Hemibagrus nemurus. Pertanika J. Trop. Agric. Sci 36: 71-78.

44. Audu IW, Ofojekwu PC (2010) Comparative effects of carp pituitary extract CPE and ova prim on induced breeding of African catfish, Clarias gariepinus, Burchell, 1822: Nigerian Journal of Experimental and Applied Biology 11: 1.

45. Yisa TA, Lamai SL, Tsadu SM, Kolo RJ (2016) Effect of incision variation length on Heterobranchus bidorsalis male spawners to extract milt for induced breeding. American Journal of Experimental Agriculture. 10: 1-7.

46. Müller T, Kucska B, László H, Ittzés A, Urbányi B, et al. (2018) Successful, induced propagation of African catfish (Clarias gariepinus) by ovarian lavage with sperm and hormone mixture. Aquaculture 485: 197-200.

47. Németh Á, Orbán K, Faidt P, Horváth Á, Müller T, et al. (2012) Induction of ovulation in the pikeperch (Sander lucioperca L.) by ovarian lavage. J Appl Ichthyol 28: 914-915.
48. Athanassopoulou F, Pappas IS, Bitchava K (2009)An overview of the treatments for parasitic disease in Mediterranean aquaculture. Options Méditerr Ser A 86 : 65-83.

49. Picón-Camacho SM, Marcos-Lopez M, Beljean A, Debeaume S, Shinn AP (2012) In vitro assessment of the chemotherapeutic action of a specific hydrogen peroxide, peracetic, acetic, and peroctanoic acid-based formulation against the free-living stages of Ichthyophthirius multifiliis (Ciliophora). Parasitology Research 110: 1029-1032.

50. Hossain MB, Rahman MM, Sarwer MG, Ali MY, Ahamed F, et al. (2013) Comparative study of carp pituitary gland (PG) extract and synthetic hormone ovaprim used in the induced breeding of stinging catfish. Heteropneustes fossilis (Siluriformes: Heteropneustidae). Our Nature 10: 89-95.

51. Sahoo SK, Giri SS, Para-ManiK M (2014) Effect of carp pituitary extract dose and latency period combinations on the stripping response of Clarias batrachus (Linnaeus, 1758) during induced spawning operation. Indian Journal of Fisheries 61: 128-130.

52. El-Hawarry WN, El-Rahman SHA, Shourbela RM (2016) Breeding response and larval quality of African catfish (Clarias gariepinus, Burchell 1822) using different hormones/hormo nal analogues with dopamine antagonist. The Egyptian Journal of Aquatic Research 42: 231-239.

53. Adeyemo OK, Alarape SA, Emikpe BO (2011) Reprotoxic effect of malachite green on African catfish Clarias gariepinus (Burchell, 1822). Journal of Fisheries and Aquatic Science 6: 563-570.

54. Adeyemo OK, Akano O, Emikpe BO (2012) Effect of formalin on spawning success and organ histology in Clarias gariepinus. Research Journal of Environmental Toxicology 6: 42.

55. Orji RCA, Nnadi CN, Onyike G (1997) Effect of different salinity levels on the fertilization and hatching of Heterobranchus bidorsalis. NAGA the ICLARM Quarterly pp. 21-22

56. Müller T, Binder T, Váradi B, Bercsényi M (2001) Artificial induction of sexua maturation and successful egg release of European eel, Anguilla anguilla. Halászat 94: 115-118 (in Hungarian with English summary).

57. Di Biase A, Casalini A, Emmanuele P, Mandelli M, Lokman PM, et al (2016) Controlled reproduction in Anguilla anguilla (L) comparison between spontaneous spawning and stripping-insemination approaches. Aquac Res. 47: 3052-3060.

58. Yeung CM, Chan CB, Leung PS, Cheng CHK (2006) Cells of the anterior pituitary. Int J Biochem Cell Biol 38: 1441-1449.

59. Woynarovitch E, Horvath L (1980) La Reproduction Artificielle des Poissons en eau Chaude: Manuel de Vulgarization, Food and Agricultural Organization Document, Techpeches. 201: 191.

60. Viveen WJAR, Ritcher CJJ, Van Oordt PGWJ, Janseen JAL, Huisman EA (1985) Practical manual for the culture of the African Catfsh Clarias gariepinus. Section for Research and Development Co-operation, The Hague, Netherlands p: 121.

61. Teugels GG (1986a) Taxonomy, phylogeny, biogeography of catfishes (Ontario physi, Siluroide: An Overview) Aquat Living Resour 9: 34. 